\title{
Geo-Electrical Data Analysis to Demarcate Groundwater Pocket Zones In Kaltungo And Environes, Northeastern Nigeria.
}

\author{
A. G. Mohammed* \& A. Ibrahim.* \\ *Department of Geology, Gombe State University, Nigeria
}

\begin{abstract}
Investigation have been made for groundwater exploration using Vertical Electrical Sounding (VES) data acquired from 6 (six) locations distributed in Kaltungo and Environs with a maximum electrode spread of $A B / 2=100 \mathrm{~m}$. This is an attempt to obtain useful information on the aquifer distribution within the area and hence delineate possible areas for groundwater development. Based on Iso-resistivity maps, geo-electric section, Longitudinal Unit conductance parameters for aquifer characteristics shows the southeastern part of the study area as favorable area for Groundwater exploration.

The groundwater potential zone has been identified based on geo-electrical, iso-resistivity and Longitudinal Unit Conductance. Based on these studies the average resistivities of all the layers are $\rho_{1}=67.1$, $\rho_{2}=20, \rho_{3}=99.1$, and $\rho_{4}=235.8 \mathrm{ohm}$ and an average thicknesses of $h_{1}=0.9, h_{1}=15.4$, and $h_{1}=52.9 \mathrm{~m}$ respectively. The Dar Zarrouk parameters for aquifer characteristics also shows an average Longitudinal conductance as $L_{1}=0.09, L_{2}=0.52$, and $L_{3}=0.422$ Siemens and Transverse Resistance of $S_{1}=128, S_{2}=$ 1215.7, and $S_{3}=2236.8 \mathrm{ohm}-\mathrm{m}$. The vertical geo-electrical section and spatial distribution of secondary parameters are constructed. The areas with $<0.4$ Siemens anisotropy are considered to be areas of high Porosity/Permeability and areas with $>0.5<0.65$ Siemens are considered areas with intermediate Porosity/Permeability while areas with $>0.65$ Siemens are considered as Low Porosity/Permeability.
\end{abstract}

Key Words: Aquifer, Dar Zarrouk, Groundwater, Longitudinal Conductance, Permeability, Porosity.

\section{Introduction}

The regional geology of the Benue Trough of Nigeria based on the previous work has been reviewed a number of times. It is an elongated $\mathrm{NE}-\mathrm{SW}$ trending intracratonic sedimentary basin located at a re-entrant in the West African continental margin, which includes the Niger, Benue and Gongola Rivers. The Benue Trough extends from the Southwest, which bounded by the Niger-Delta and to the Northwest bounded by the Chad Basin; it is approximately $800 \mathrm{~km}$ long and $130-150 \mathrm{~km}$ wide. The trough was filled with cretaceous rocks whose ages ranges from middle Albian - upper Paleocene and bordered on either side by granite and gneisses of probably protozoic age which make up the crystalline basement [1], [2], and [3]. Igneous actually of Tertiary age intruded the Basement Complex Age Sedimentary rocks. The Benue trough is geographically subdivided into three (3) parts: The Upper or Northeast region, Middle Benue or Lafia-Muri area, and the Lower Benue which is the area south and west of Makurdi.

The sedimentary and stratigraphic aspect of the Benue Trough was first described by [4], [5]. The first Interpretation on the Origin of Benue Trough was proposed by [6]. The Trough has been generally accepted to be a rift structure due to major fault along it [1]. But recently, with the emergence of the Sea floor spreading and plate tectonic hypothesis [7] proposed a new theory for the origin. They contended that the Rift first opened in Cretaceous as a result of the spreading of a crustal ridge in the region of the present valley this according to them ceased by late Cretaceous and then was followed by a closing episode of the North Atlantic and South Atlantic African Plates in the Santonian.

The Benue trough has also been considered as a "Failed arm" (Aulacogen of the triple junction due to its tectonic setting, rift origin and its rock sedimentary deposit, [8] and [9].

Based on geomorphic, geophysical and paleontological evidence, three (3) major theories were postulated to explain not only the origin but also the mechanism responsible for the formation of the Trough. [7] Suggests that the evolution of the Trough is related to the stresses that accompanied the separation of South America from Africa [1], [8] [10] and others accepted this and developed it by using stratigraphic structures and geophysical data.

Almost all these workers tend to agree that the evolution of the Benue trough (Depression) is intimately connected to that of the South Atlantic Ocean. [11] Suggest that the Gulf of Guinea, the Benue depression and the South Atlantic developed between RRR (Ridge-Ridge-Ridge) triple junction, one situated under the present Niger Miogeosynchine and other situated north of the Takafu rift structure of Guyana. This structure linked the North and South Atlantic opening, [8] gave a plate tectonic model. In which they portrayed the trough as originating as a triple junction. They proposed on RRR (Ridge-Ridge-Ridge) triple junction and this appears to account more satisfactory for the present arrangement of transform fracture zones in the Gulf of Guinea region. 
The study area falls within the Northern (Upper) Benue trough bounded by Latitudes N9 $37^{\prime} 02^{\prime \prime}$ and N9 ${ }^{\circ} 39^{\prime}$ $41^{\prime \prime}$ with Longitudes E11 $04^{\prime} 02^{\prime \prime}$ and E $11^{\circ} 06^{\prime} 28^{\prime \prime}$ with an approximate total area of $37.5 \mathrm{~km}^{2}$ (Fig 1).

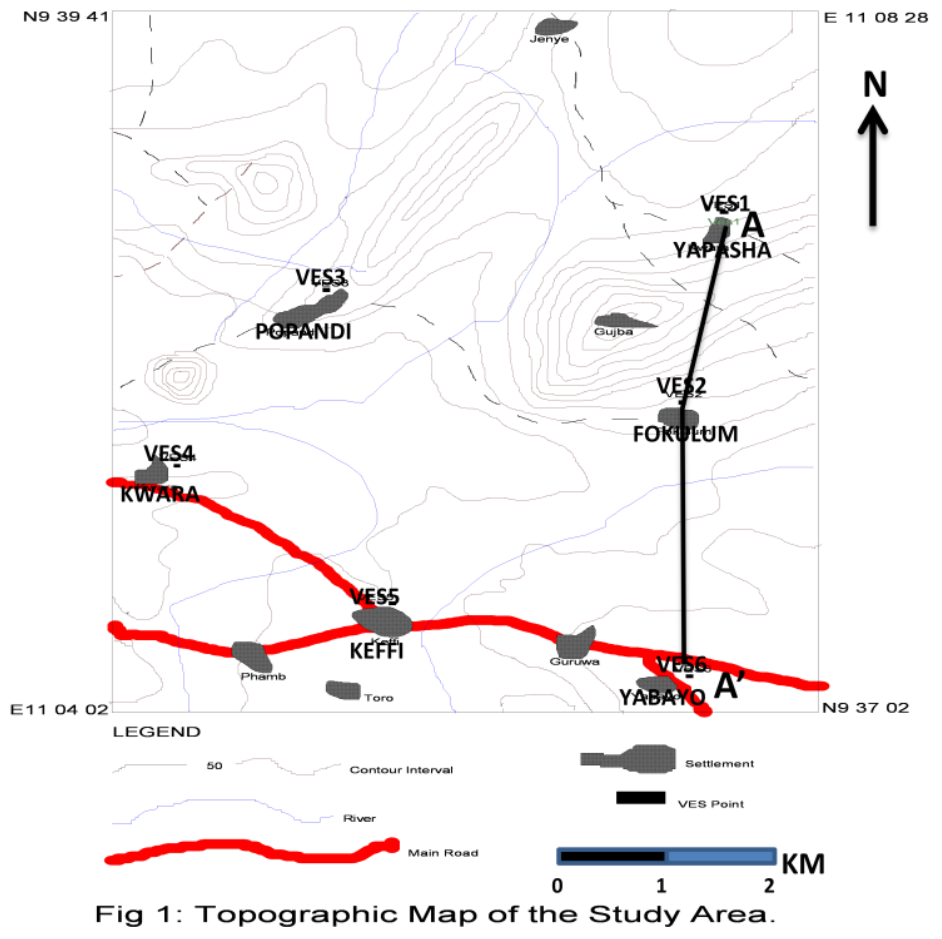

II. Material And Method Of Study

This work involves the application of resistivity method to locate sites that will be suitable for drilling of boreholes. Vertical electric sounding was carried out at six (6) different positions using Terrameter SAS 1000 which gives a direct readout resistance using Schlumberger method of electrode spread of maximum $A B / 2=$ $100 \mathrm{~m}$. The interval between the potential and current electrodes was increased only a few times and in relatively small steps in order to obtain the differences large enough to be measured with satisfactory precision. In this method, a fixed point called the VES station was marked and noted; two electrodes $\left(\mathbf{C}_{\mathbf{1}} \mathbf{C}_{2}\right)$ of equal distance on the opposite sides of the VES station were measured and driven into the ground with the ground with the aid of a sledge hammer for proper contact to be made with the ground, similarly, two other electrodes called the potential electrodes $\left(\mathbf{P}_{\mathbf{1}} \mathbf{P}_{\mathbf{2}}\right)$ of equal distance and between the current electrodes were measured and driven in to the ground with the aid of the sledge hammer. The arrangements of the current and potential electrodes were in such a way as to maintain a straight line. These pair of electrodes was connected to the Terrameter through points $\mathbf{A B}$ and $\mathbf{M N}$.

The Terrameter was switch "ON" and current was introduced artificially in to the ground through the pair of electrode $\left(\mathbf{C}_{1} \mathbf{C}_{2}\right)$ and the resulting potential difference due to the current were measured through the other pair of electrode $\left(\mathbf{P}_{\mathbf{1}} \mathbf{P}_{\mathbf{2}}\right)$, thereafter, the Terrameter was switched "OFF". The current electrodes were moved equally away on the opposite sides of the fixed point (VES) according to designed acquisition parameter in this study the design is 1, 1.5, 2, 2.5, 3,4,5,6.5,8,10,15,20,25,30,40,50,65,80 and 100m $\left(\mathbf{C}_{\mathbf{1}} \mathbf{C}_{2}\right)>>\left(\mathbf{P}_{\mathbf{1}} \mathbf{P}_{\mathbf{2}}\right)$ and the readings were recorded at every new position. [12]; [13]; [14]; [15]; [16]. The field procedure consists of expanding current electrodes $\left(\mathbf{C}_{\mathbf{1}} \mathbf{C}_{\mathbf{2}}\right)$ while holding potential electrodes distance $\left(\mathbf{P}_{\mathbf{1}} \mathbf{P}_{\mathbf{2}}\right)$ fixed. This process yields a rapidly decreasing potential difference across $\left(\mathbf{P}_{\mathbf{1}} \mathbf{P}_{\mathbf{2}}\right)$, which ultimately exceeds the measuring capabilities of the instrument. At this point, a new value for potential distance was established, typically five times greater than the proceeding value and the survey was continued [17]; 1966; [14]. The systematic movement of the current and potential electrodes continued until the survey was completed [18].

\section{Result And Discussion}

Kaltungo and environs is within the Northern (Upper) Benue Trough. Qualitative analysis of the curve types by inspection revealed that the area has VES1, VES2, VES3, VES4, and VES5 as H-type curves and 
VES6 as K-type curve (Fig 2). Since groundwater accumulates in sedimentary rocks (sands, gravels, silt, limestone, etc.), and in weathered overburden, joints, fractures and faults zones in crystalline basement rocks, the electrical resistivity of subsurface materials (rocks, minerals, etc.) can be determined by the subsurface resistivity distribution to the ground which is at times related to the physical conditions of interest such as lithology, porosity, degree of water saturation and presence or absence of voids in the rocks [19]. The VES method of electrical resistivity gives detailed information of vertical succession of individual thicknesses, resistivities and their different conducting zones. In each case, the VES was used to delineate the subsurface Stratigraphy based on resistivity differences; from those values the aquifer thickness and other parameters were established.

Two types of sounding curves have been identified from the study area, these are H-type curves and K-type of curve and the layers vary from three to four layers.

H-type: The curves are characterized by high-low-high resistivity characteristics depicting a low resistivity value at the centre (fig 2).

K-type: The curve is characterized by low-high-low resistivity characteristics depicting a high resistivity value at the centre (fig 2).

Table 1: Summary of Geo-electric Parameters

\begin{tabular}{|c|c|c|c|c|c|}
\hline S/No & VES Location & Coordinates & $\begin{array}{l}\text { VES } \\
\text { No }\end{array}$ & $\begin{array}{l}\text { Layer } \\
\text { Resistivity } \\
\text { (Ohm-m) }\end{array}$ & $\begin{array}{l}\text { Layer } \\
\text { Thickness } \\
\text { (m) }\end{array}$ \\
\hline 1 & YAPASHA & $\mathrm{E} 11^{\circ} 01^{\prime} \mathrm{N} 9^{\circ} 38^{\prime}$ & 1 & $94.1,57.1,314.6$ & $0.9,17.3$ \\
\hline 2 & KEFFI & $\mathrm{E} 11^{\circ} 03^{\prime} \mathrm{N} 9^{\circ} 35^{\prime}$ & 5 & $22.3,16.2,23.2$ & $0.7,21.6$ \\
\hline 3 & YABAYO & $\mathrm{E} 11^{\circ} 04^{\prime} \mathrm{N} 9^{\circ} 35^{\prime}$ & 6 & $16.9,30.0,9.2$ & $0.7,14.6$ \\
\hline 6 & FOKULUM & $\mathrm{E} 11^{\circ} 04^{\prime} \mathrm{N} 9^{\circ} 37^{\prime}$ & 2 & $86.9,23.0,39.9$ & $1.0,27.9$ \\
\hline 4 & POPANDI & $\mathrm{E} 11^{\circ} 03^{\prime} \mathrm{N} 9^{\circ} 38^{\prime}$ & 3 & $96.8,54.4,111.9,165.1$ & $1.5,9.1,59.7$ \\
\hline 5 & KWARA & $\mathrm{E} 11^{\circ} 02^{\prime} \mathrm{N} 9^{\circ} 36^{\prime}$ & 4 & $85.4,41.8,96.5,306.4$ & $0.8,7.8,46.1$ \\
\hline
\end{tabular}

TABLE 2: LONGITUDINAL CONDUCTANCE AND TRANSVERSE RESISTANCE IN THE STDY AREA.

\begin{tabular}{|c|c|c|c|c|c|c|c|c|c|}
\hline \multirow[t]{3}{*}{ S/No } & \multirow{3}{*}{$\begin{array}{l}\text { Geo-electric } \\
\text { Earth Layer } \\
\text { Model }\end{array}$} & \multicolumn{4}{|c|}{ Longitudinal Conductance } & \multicolumn{3}{|c|}{ Transverse Resistance } & \multirow{3}{*}{$\begin{array}{l}\text { Total } \\
\text { Depth } \\
(\mathrm{m}) \\
\end{array}$} \\
\hline & & \multicolumn{4}{|c|}{ (Siemens) } & \multicolumn{3}{|c|}{$\Omega m^{2}$} & \\
\hline & & VES Type & L1 & L2 & L3 & S1 & S2 & S3 & \\
\hline 1 & 3-Layer & $\mathbf{H}$ & 0.0093 & 0.302 & & 82.37 & 986.7 & & 18.1 \\
\hline 2 & 3-Layer & $\mathbf{H}$ & 0.145 & 0.878 & & 58.3 & 217.9 & & 22.3 \\
\hline 3 & 3-Layer & $\mathbf{H}$ & 0.105 & 0.878 & & 40.4 & 767.3 & & 15.3 \\
\hline 4 & 3-Layer & $\mathbf{K}$ & 0.122 & 0.538 & & 63.4 & 222.1 & & 29.4 \\
\hline 5 & 4-Layer & $\mathbf{H}$ & 0.17 & 0.379 & 0.441 & 425.6 & 4852 & 2534.6 & 70.3 \\
\hline \multirow[t]{2}{*}{6} & 4-Layer & $\mathbf{H}$ & 0.0119 & 0.174 & 0.422 & 98.13 & 248.2 & 2236.8 & 54.7 \\
\hline & \multicolumn{2}{|l|}{ AVERAGE } & 0.0939 & 0.524 & 0.422 & 128.03 & 1215.7 & 2236.8 & 35 \\
\hline
\end{tabular}

TABLE 3: AVERAGES OF THE PARAMETERS IN THE STUDY AREA.

\begin{tabular}{|c|c|c|c|c|c|c|c|c|}
\hline \multirow[b]{2}{*}{ VES No } & \multirow[b]{2}{*}{ Location } & \multicolumn{3}{|c|}{ RESISTIVITIES $(\Omega \mathrm{m})$} & \multirow[b]{2}{*}{$\rho 4$} & \multicolumn{3}{|c|}{ DEPTH(m) } \\
\hline & & $\rho 1$ & $\rho 2$ & $\rho 3$ & & h1 & h2 & h3 \\
\hline VES1 & YAPASHA & 94.1 & 57.1 & 314 & & 0.9 & 11.3 & \\
\hline VES2 & FOKULUM & 86.9 & 23 & 39.9 & & 1 & 27.9 & \\
\hline VES3 & POPANDI & 96.8 & 54.4 & 111.9 & 165.1 & 1.5 & 9.1 & 59.7 \\
\hline VES4 & KWARA & 85.4 & 41.8 & 96.5 & 306.4 & 0.8 & 7.8 & 46.1 \\
\hline VES5 & KEFFI & 22.3 & 16.2 & 23.2 & & 0.7 & 21.6 & \\
\hline VES6 & YABAYO & 16.9 & 30 & 9.2 & & 0.7 & 14.6 & \\
\hline AVERAGE & & 67.1 & 20 & 99.1 & 235.8 & 0.93333 & 15.4 & 52.9 \\
\hline
\end{tabular}



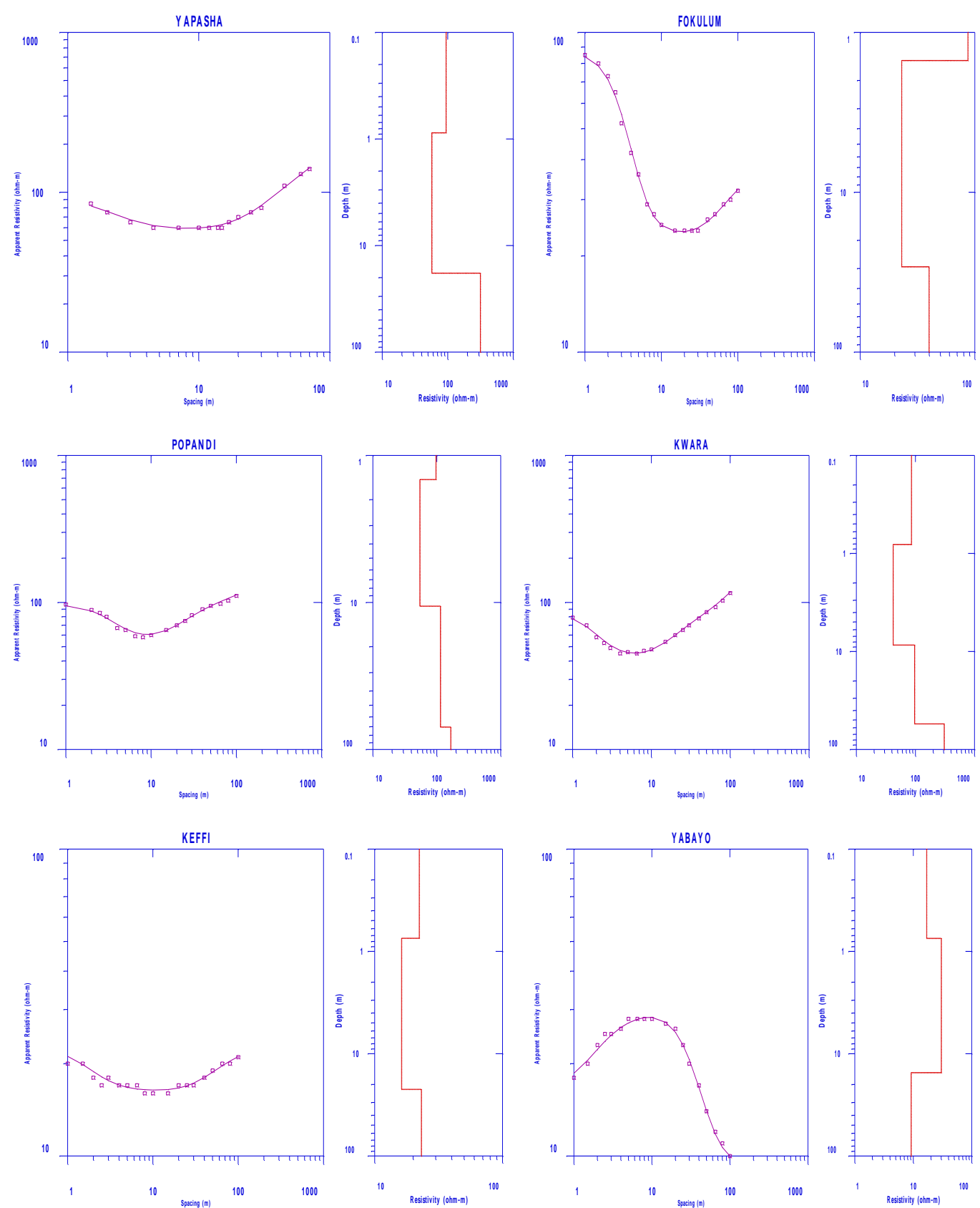

Fig 2: Computed VES data of the Study Area.

TABLE 4: DATA OF ISO-RESISITIVITY/ LONGITUDINAL UNIT CONDUCTANCE OF THE STUDY AREA.

\begin{tabular}{l|cccccc}
\multicolumn{1}{c}{ DATA } & VES1 & VES2 & VES3 & VES4 & VES5 & VES6 \\
AB/2=80m $(\mathbf{\Omega} \mathbf{m})$ & 140 & 30 & 103 & 103 & 20 & 11 \\
Second Layer $(\mathbf{\Omega})$ & 57 & 23 & 54 & 42 & 16 & 30 \\
Dar Zarrouk (Siemens) & 0.302 & 0.878 & 0.878 & 0.538 & 0.379 & 0.174 \\
\hline
\end{tabular}

\section{ISO-RESISTIVITY MAP AT 80/2m.}

Iso-resistivity map was prepared by plotting the resistivity obtained from sounding curves at a given electrode spacing common to all the sounding points for $\mathrm{AB} / 2=80 \mathrm{~m}$ (fig 3 and 4 ). Points of equal resistivity values are contoured. This is a qualitative interpretation that represents the variation in resistivity at a given electrode spacing and also indicates the general lateral change in the electrical properties around the area. The study area has anomalies high at the Northern part with resistivity reaching a maximum value of $103 \mathrm{ohm}-\mathrm{m}$ at 
(Yapasha) with another one with same maximum value of 103ohm-m at (Popandi) Fig 1. While major anomaly low were depicted in the study area one around the Southeastern portion of the study area with a maximum value of 20ohm-m (Keffi) and 110hm-m in (Yabayo). This reveals the southeastern part of the study area as the potential zone for groundwater exploration Fig 3.

Iso-resistivity map of the second layer (aquifer zone) plotted also reveals similar trend as that of the $\mathrm{AB} / 2=80 \mathrm{~m}$ with anomalies high at the Northern part of the study area with resistivity reaching a maximum value of $57 \mathrm{ohm}-$ $\mathrm{m}$ at (Yapasha) with another one with a maximum value of 54ohm-m at (Popandi) Fig 1. While major anomaly low were depicted in the study area around the Southeastern portion of the study area with a maximum value of 16ohm-m at (Keffi) and 30ohm-m in (Yabayo) Fig 4.

\section{Dar Zarrouk parameters for aquifer characteristics.}

Longitudinal conductance and Transverse Unit resistance $(\mathbf{S} \& \mathbf{T})$ : The longitudinal unit conductance values vary from 0.00929 to 0.878 Siemens in the study area. The qualitative use of this parameter is to demarcate changes in the total thickness of low resistivity materials [20]; [21]. The conductivity and transverse resistance of layers clarify a strong interpretation apart from any previous analysis of under groundwater [22]. These applications are beyond the usual hydrogeological use of VES; these two factors (conductivity and transverse resistance) commonly yield the characteristics of aquifers [23]. Instead of this approach, it is advantageous to consider the combination of the resistivity and the thickness of rock layers as a basis in evaluating some related properties such as the transmissivity (T) and the Storatability (S) of the aquifers. Ultimately, such approach could be oriented towards evaluating and protecting groundwater resources [24]. The graphical procedures are discussed by [25], Keller and [18]. The application of these parameters is discussed by [26]; [27] and [28] in different geological conditions. The aquifer resistance (Average resistivity times Aquifer thickness) proposed by [30] has been used in the present research work.

\section{Coefficient of Anisotropy ( $\lambda$ ) LONGITUDINAL CONDUCTANCE}

Generally the anisotropy is $<1$ and does not exceed 2 in most of the geological conditions [29]. Compact rock at shallow depth increases the coefficient of anisotropy [18]. Hence these areas can be associated with low porosity and permeability, the values of anisotropy ranges from 0.2 to 0.85 in the study area. The areas with 0.55 and less are considered for groundwater potential zones with high porosity and permeability, a perpendicular and another parallel to the layering [30]. In this context, the parameter of longitudinal conductance $(\mathrm{L})$ is associated with the flowing current parallel to stratification and given by the ratio between the thickness of the layer and its resistivity. For a set of $n$ layers of a section, this conductance is defined by:

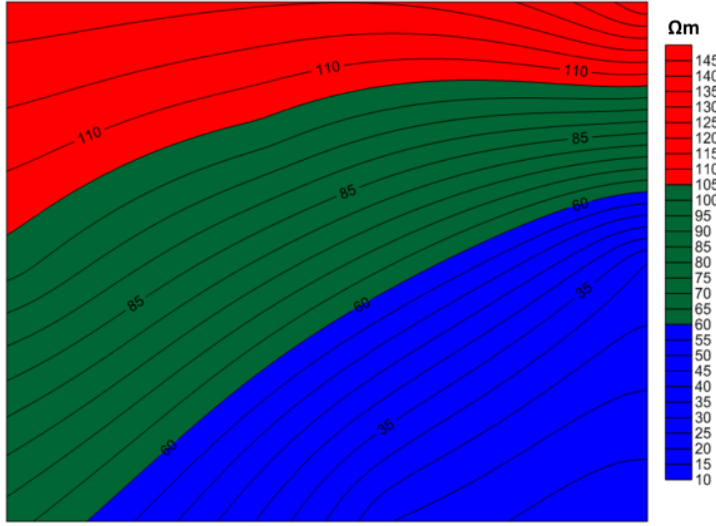

Fig 3a: ISO-RESISTIVITY MAP AT 80/2m. resistivity of at $\mathrm{AB} / 2 \mathrm{~m}$

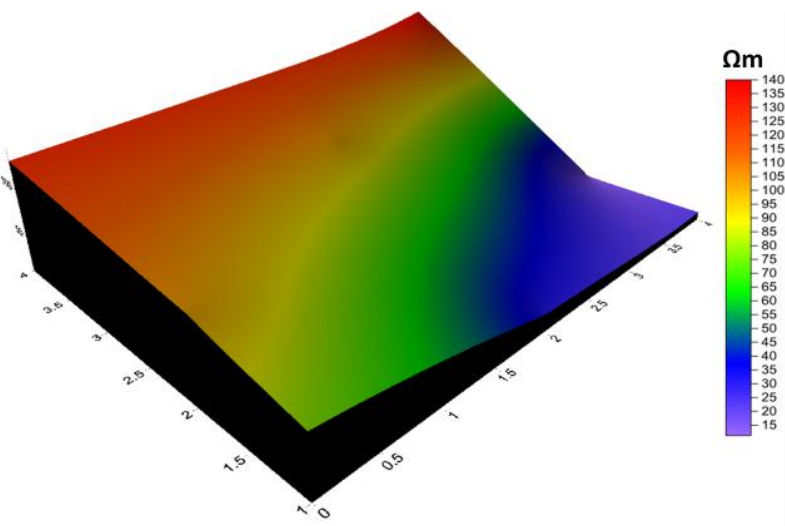

Fig 3b: 3D Surface Map of Iso- 

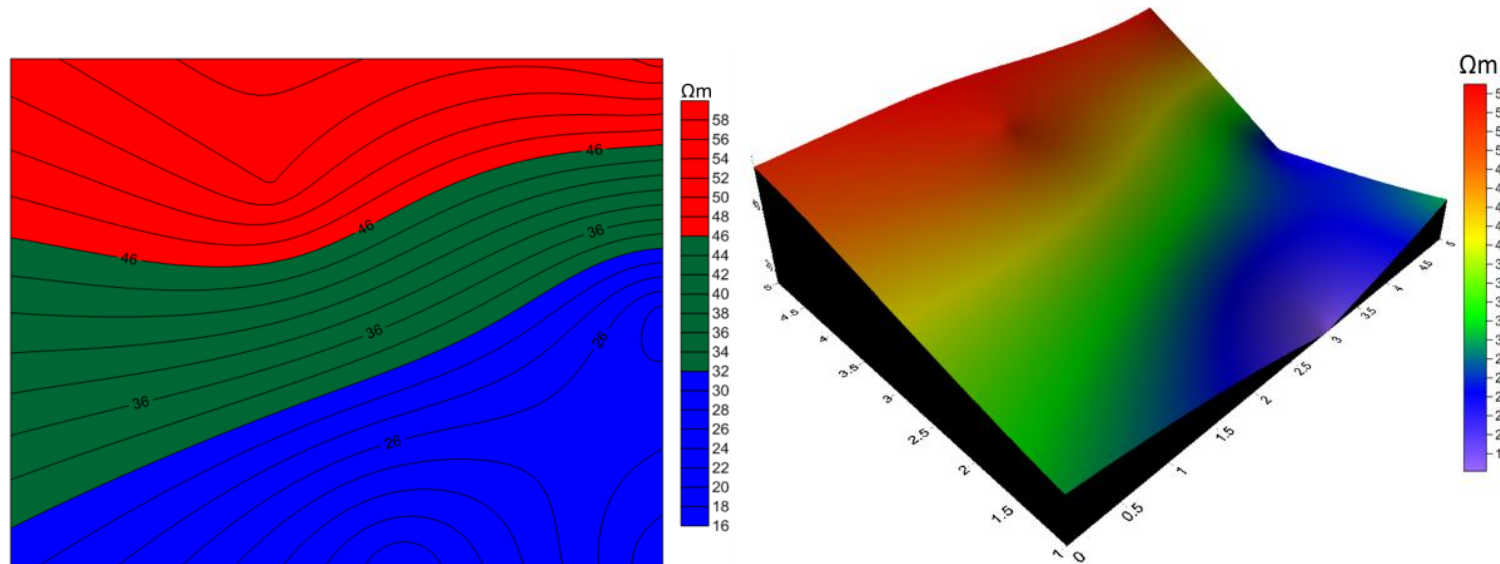

Fig 4a: ISO-RESISTIVITY MAP OF THE SECOND LAYER. THE SECOND LAYER

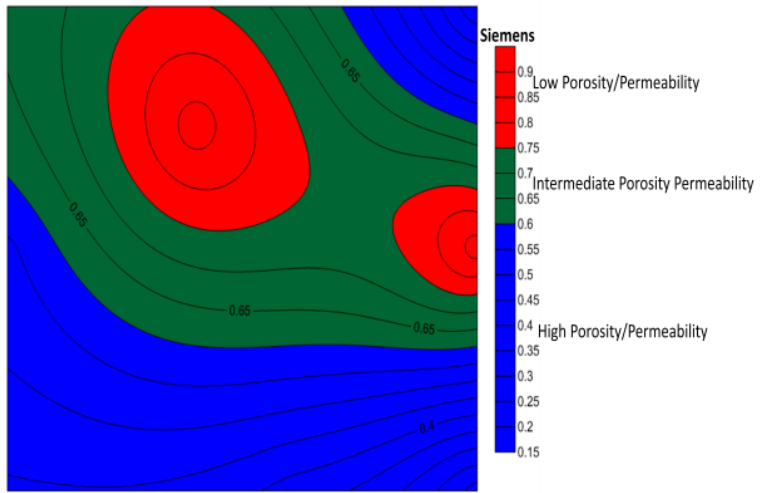

Fig 5a: LONGITUDINAL UNIT CONDUCTANCE CONDUCTANCE

CONTUOR MAP OF THE STUDY AREA. STUDY AREA.

$L i=\sum_{i}^{\infty}\left(\frac{E i}{\rho i}\right)$

Where:

Ei and $\rho i$ are respectively the resistivities and thicknesses of each layer belonging to the unsaturated zone, which was characterized and interpreted in the IXD software. Thus, the calculation of longitudinal conductance parameter was conducted in a punctual way for each VES executed, and subsequently subjected to gridding and interpolation along the studied area, obtaining a map of isolines related to the "L" parameter Fig 5.

\section{SUB SURFACE GEO-ELECTRIC SECTION ALONG A-A'.}

Commonly a geo-electric section constructed from the analysis of VES data coincide with the corresponding geological sections. Layers of different lithology with the same age may have the same resistivity and they form a single geo-electric layer. Anisotropy of the subsurface layers is another factor which will introduce errors in the estimates of true resistivity and depths in the interpretation of VES curves, [19]. Geoelectric section was constructed along profile A-A' (Fig 6), the top soil has a resistivity values ranging from 17 to $94 \mathrm{ohm}-\mathrm{m}$ with thicknesses of $1 \mathrm{~m}$. This layer consists of red sandy soil. These followed by the weathered basement with ranging resistivities of $23 \mathrm{ohm}-\mathrm{m}$ and $57 \mathrm{ohm}-\mathrm{m}$ and a ranging thickness of 15 to $28 \mathrm{~m}$. Followed by the weathered/fractured with basement clay with a resistivity ranging from 9 to $315 \mathrm{ohm}-\mathrm{m}$ with infinite depths. As can be seen from Fig 6 VES2 (Fokulum) has about 28m thick aquifer hence favorable for site of borehole which can also be confirmed from VES2 Model Fig 2. 


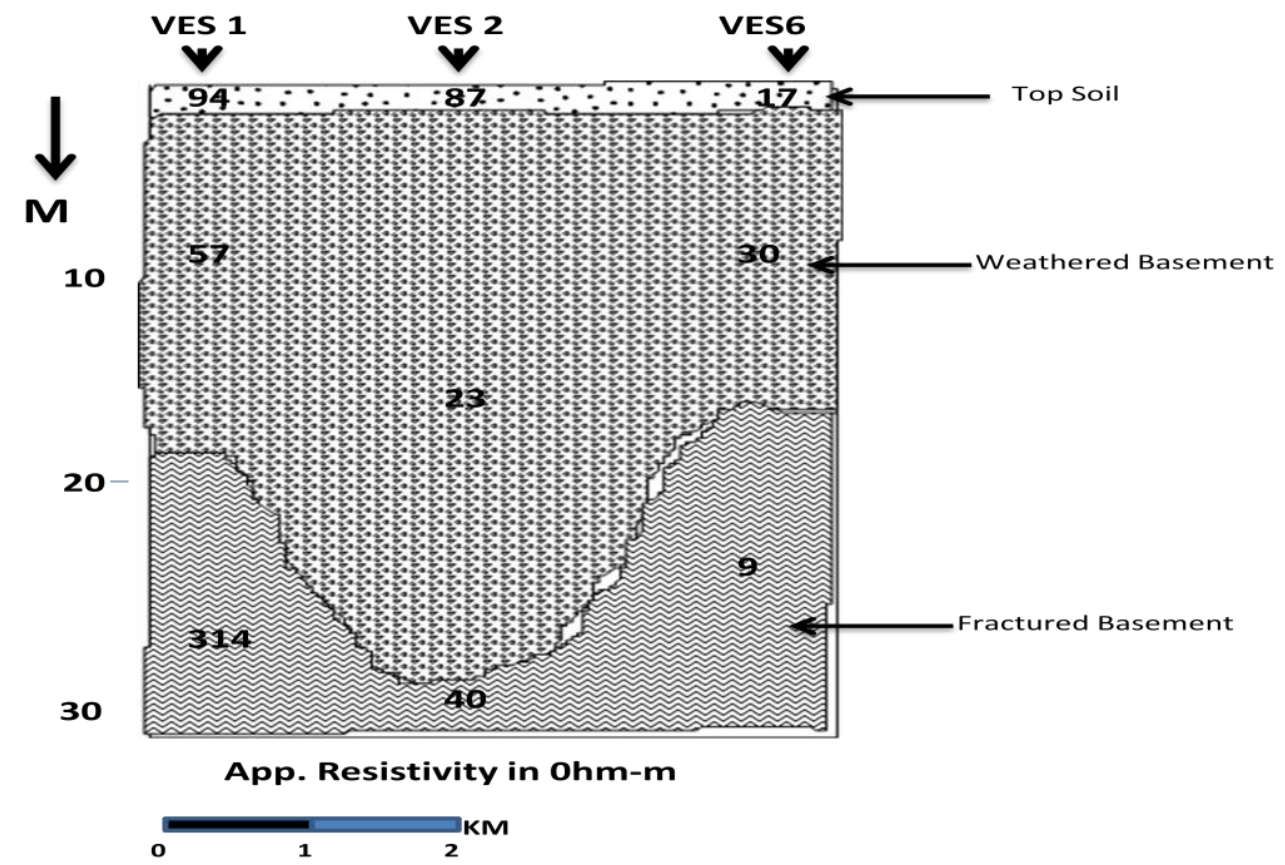

Fig 6: SUB SURFACE GEO-ELECTRIC SECTION ALONG A-A'.

\section{Coclusion:}

The geophysical method used in this study has assisted as a good alternative to investigate the groundwater potential of some selected areas in Kaltungo area of Gombe State. The study revealed Kaltungo town and her environs as basement area with reasonable weathered formation ranging from a total depth of $18.1 \mathrm{~m}$ to $54.7 \mathrm{~m}$ which make it possible to demarcate thick soil pockets followed by considerable thickness of aquifers as recharge pockets. Interpretation of the VES, Iso-resistivity Maps and profiles identified some conductive zones which were considered as priority areas for groundwater exploration. The geo-electric parameters obtained from the inverted Vertical Electrical resistivity sounding data were used to delineate the aquifer types of the area, fractured bedrock and/or weathered bed rock. Also cross- section and contoured maps which were analyzed based on hydro-geological importance of the study area were evolved. Based on these, the area was categorized into high, intermediate and low groundwater potential. Analysis of the geophysical survey data revealed that the study area could play a significant role in providing adequate portable water for the rural dwellers.

It is, however, recommended that more sophisticated and effective geophysical methods such as aerial remote sensing, seismic refraction, electrical tomography and depth probing electromagnetic instrument: ABEM WADI VLF instrument which detects fractures, the depth to the conductive zone and its dip and electrical resistivity sounding equipment: SAS 4000 (Lund Imaging System) for better imaging of the subsurface and to obtain data of better quality. Above all, development of some of the sites investigated (VES2, VES5 and VES6) will encourage the dwellers to adopt irrigation farming thereby improving their socio-economic and agricultural status.

\section{References}

[1]. Carter, J. D., Barber, W., Tait, E. A (1963); The Geology of parts of Adamawa, Bauchi and Borno provinces in Northern Nigeria. No 30.

[2]. Oyawoye (1972): The Basement Complex of Nigeria. In Dessauvagie TFY, whiteman AJ(eds) African geology, Ibadan University press, pp66-102.

[3]. McCurry, p(1976): The Geology of the Precambrian to Lower Paleozoic Rocks of North Nigeria - A Review in : Kogbe CA (ed) Geology of Nigeria. Elizabethan publisher, Lagos, pp 15-39.

[4]. Falconer, J. D., 1911. The Geology and Geography of Northern Nigeria. London Macmillan, pp. 135-136.

[5]. Wilson and Basic (1928). The sedimentary and stratigraphic aspect of Benue trough (Nigeria).

[6]. King L.C(1950);Speculation on the outline and the mode of disruption of Gondwanaland.Geol.Magazine pp 353-359.

[7]. Burke Dessauvagie, T.F.J, and Whiteman,A.J (1970): Geological History of the Benue Valley and adjacent Areas in African Geology. Pp187-205, Ibadan University press. Ibadan, Nigeria.

[8]. Olade, M.A (1975): Evolution of Nigeria's Benue Trough (Aulacogen); A tectonic Model, Geological Magazine 112:575-583.

[9]. McConnel (1975). The geophysical, paleontological Geomorphic Evidence Based on Origin and Mechanism for the formation of Benue trough (Nigeria)

[10]. Oseji J. O.; Asokhia M. B. and Okolie E. C. (2006). "Determination of Groundwater potentials in Obiaruku and environs Using Surface geo-electric Sounding”. The Environmental Springer Science + Bussiness Media. DO1 10.10669-006-0159-x 26: 301-308 
[11]. Okolie E. C.; Osemeikhian J; Oseji J. O and Atakpo E. (2005). "Geophysical Investigation of the source of River Ethiope" in Ukwuani Local Government Area of Delta State. Nigeria. Inst Phys. Vol. 17

[12]. Osemeikhian J. E.; Asokhia M. B. (1994). “Applied Geophysics for Engineers and Geologist. Samtos Services LTD Lagos, Nigeria.

[13]. Bhattacharya, P.K., and Patra, H.P., 1968. Direct Current Geoelectric Sounding, Principles and Interpretation. Elsevier Pub. Co., New York, 135.

[14]. Jakosy J. J. (1950). "Exploration Geophysics" Second edition Trija publication Company, Los Angeles U. S. A

[15]. Shichter L. B. (1933). "The interpretation of Resistivity Prospecting method for Horizontal structures. Physics 4: 307-322.

[16]. Keller G. V. and Frischknecht F. C. (1966). "Electrical Methods in Geophysics Prospecting" Pengamon Press, New York pp 96517

[17]. Harold M. Mooney T. (1980). Hand Book of Engineering Physics Vol2 Electrical Resistivity bison instruments Inc. Minnesota U.S.A. Chapters pp 27-34.

[18]. Henriet, J. P. (1976). Direct application of the Dar-Zarrouk Parameters in Groundwater Surveys, Geophysics. Pros, 24, 344-353.

[19]. Galin, D. L. (1979). Use of Longitudinal conductance in Vertical electrical sounding Induced Potential Method for Solving Hydrogeological Problems, Vestrik Moskovskogo Univer, Geol, 34, 74-100.

[20]. Rajesh R; Sreedhara M. and Uday S. (2002). Electrical Resistivity Survey to Demarcate Potential Sites for Groundwater and Artificial recharge in part of Precambrian Crystalline province of Peninsula India. J. Appl. Hydro. 15 (2\&3), 39-48.

[21]. Kuentz G (1966). Principles of direct current resisitivity Prospecting, Berlin. Grebruder Bokmtraeger, pp 103.

[22]. Guelala, R., Inoubli, M.H., Amri, F. 2009. New elements on the structure of the Ghardimaou superficial aquifer (Tunisia): electrical geophysics results. Hydrological Sciences Journal, 54(5) : 974-983

[23]. Kalenov, E. N. (1957). Interpretation of Vertical Electrical sounding Curves, Moscow, Gostoptekhiz at, pp412.

[24]. Satya K. M. (1979). Geoelectricel and Hydrogeological Investigations on Miocene Rajahmundy Sandstones of the Lower Godavari Valley, Andhra Pradesh, PhD. Thesis.

[25]. Rama Rao, C. H. (1980). Geoelectrical Investigation on some Gondwana Sedimentary tracts for groundwater and related problems in West Godvari, Andhra Pradesh, PhD. Thesis

[26]. Prakasa Rao B. S. (19830). Studies on Development of Groundwater Potential from paloe Channels. PhD. Thesis

[27]. Venkateswara R. B. (2002). Geo-electrical Data based statistical modeling for yield of Borehole wells in a typical Khondalitic Terrain. J Appl Hydro; 15 (2\&3) pp 1-8.

[28]. Zohdy, A.A.R., 1974. A computer program for the calculation of Schlumberger sounding curves by convolution. PB-232056, National Technical Information Service, Springfield, Virginia. pp11.

[29]. Orellana E. Mooney, H. M. (1966). Master Tables and Curves for Vertical electrical Sounding over Layered Structures: Madrid Interciecia, 150 pp 66 tables. Geophysics, 28, pp99-100.

[30]. Maillet, R. (1974). The Fundamental Equations Of Electrical Prospecting, Geophysics, 2, 529-556. 